\title{
Development of the Esophagus and Stomach
}

\author{
Mukaddes EŞREFOĞLU'1 \\ ${ }^{1}$ Department of Histology and Embryology, Bezmialem Vakif University School of Medicine, İstanbul, Turkey \\ ${ }^{2}$ Department of Histology and Embryology, İnönü University School of Medicine, Malatya, Turkey
}

\section{ABSTRACT}

Epithelial components of the organs of the digestive system are derived from the endoderm, whereas connective tissue and muscle components are derived from the mesoderm. At the 3rd-4th week of development, as a result of cephalocaudal and lateral foldings of the embryo, a portion of the endoderm-lined yolk sac cavity is incorporated in the embryo to form the primitive gut. Primitive gut is composed of four main regions: pharyngeal gut, foregut, midgut, and hindgut. The esophagus and stomach are derived from the foregut. The development of the esophagus is characterized by lengthening, widening, thickening, and histological changes. The development of the stomach is characterized by widening, thickening, and histological changes as well as positional changes.

In the present study, we tried to review the morphological and functional development of the esophagus and stomach with the aid of pictures obtained from various stages of prenatal and postnatal development of the organs of rats. Previous reviews lack information on both histological and functional development of the organs.

Keywords: Esophagus, development, stomach

\section{Development of the digestive tract}

The digestive system consists of the digestive tube and its principal associated organs, namely, salivary glands, pancreas, liver, and gallbladder. It begins with the oral cavity and ends in the anal canal. The digestive tube is composed of the esophagus, stomach, small intestines (duodenum, jejunum, and ileum), and large intestines (cecum, ascending colon, transverse colon, descending colon, sigmoid colon, rectum, and anal canal). The liver and pancreas are accepted to be associated glands bound to the digestive tube by excretory ducts. Epithelial components of the organs of the digestive system are derived from the endoderm, whereas connective tissue and muscle components are derived from the mesoderm. The organs of the body are formed by the proliferation, migration, and differentiation of the stem/progenitor and mature cells.

The first 8 weeks of intrauterine development period is called as "organogenesis period" as well as "embryonic period". At the end of the 8th week, the embryo is approximately $30 \mathrm{~mm}$ in length and $2 \mathrm{~g}$ in weight. The heart is functional on the $4^{\text {th }}$ week. Primary brain vesicles are formed, and primary brain waves are detectable. At the end of this period, all of the body systems are formed but are not mature in morphological and functional manner. The development and growth of the organs continue during the fetal period. Most of the organs are fully developed at the postnatal period; still, volume increase is obvious through the puberty period. It is a matter of fact that morphological and functional maturation period is not uniform for all of the cell types.

In this review, we aimed to outline brief information about the histological features and prenatal and postnatal morphological and functional development of the esophagus and the stomach. Recent reviews lack information on both histological and functional development of these organs.

Cite this article as: Eşrefoğlu M, Taşısıdere E, Çetin A. Development of the Esophagus and Stomach. Bezmialem Science 2017; 5: 175-82. 


\section{Development of the primitive gut}

At the $3^{\text {rd }}-4^{\text {th }}$ week of development, as a result of cephalocaudal and lateral foldings of the embryo, a portion of the endoderm-lined yolk sac cavity is incorporated in the embryo to form the primitive gut. Primitive gut is composed of four main regions, namely, pharyngeal gut, foregut, midgut, and hindgut (Figure 1). The pharyngeal gut is separated from the primitive oral cavity by the buccopharyngeal membrane, whereas the foregut extends to the cloacal membrane that is the boundary between endoderm and ectoderm (19). The pharyngeal gut extending from the buccopharyngeal membrane to the tracheobronchial diverticulum consists of pharyngeal (branchial) archs, pharyngeal clefts, and pharyngeal pouches. Five pairs of pharyngeal pouches lined by the endoderm give rise to the middle ear cavity, auditory tube, tympanic membrane (first one), palatine tonsils (second one), thymus and inferior parathyroid glands (third one), superior parathyroid glands (fourth one) and finally, parafollicular cells of the thyroid gland (fifth one). The foregut lies caudal to pharyngeal tube and extends as far caudally as the liver outgrowth. The respiratory system, esophagus, stomach, proximal part of the duodenum, liver, pancreas, and gallbladder are derived from the foregut. The midgut begins caudal to the liver bud and extends to the junction of the right two-thirds and left third of the transverse colon in adult. Thus, the distal part of the duodenum, jejunum, ileum, cecum, appendix, and ascending colon and the proximal part of the transverse colon are derived from the midgut. Finally, the last part of the primitive gut that extends from the caudal end of the midgut to the cloacal membrane gives rise to the distal part of the transverse colon, descending colon, sigmoid colon, and rectum (Figure 1) $(1-3,5,6)$.

\section{Esophagus}

\section{Histology of the esophagus}

The esophagus consists of the mucosa, submucosa tunica muscularis (muscularis externa), and adventitia/serosa. The mucosa is composed of the epithelium, lamina propria, and muscularis mucosa. In adults, the surface epithelium is nonkeratinized stratified squamous in type. Lamina propria, loose connective tissue, has some mucous glands called as "esophageal cardiac glands" at the proximal and distal ends of the esophagus. The muscularis mucosa is a longitudinally arranged smooth muscle layer. The submucosa, which is denser than the lamina propria, contains mucous tubuloalveolar esophageal glands proper. The nerve fibers and ganglion cells comprise the submucosal plexus (Meissner's plexus). The tunica muscularis is arranged as inner circular and outer longitudinal muscle layer. The upper one-third consists of striated muscle, the middle third consists of striated and smooth muscle, and the lower third consists of only smooth muscle. Another nerve plexus, the myenteric plexus (Auerbach's plexus), is present between the outer and inner muscle layers. The outermost layer is the adventitia above the diaphragm and the serosa below the diaphragm $(10,11)$.

\section{Development of the esophagus}

At the $4^{\text {th }}$ week of development, the respiratory diverticulum (tracheobronchial diverticulum) appears at the ventral wall of the foregut. The tracheoesophageal septum formed between the respiratory diverticulum and the distal part of the foregut separates these two portions. Thus, the foregut is divided into the ventral respiratory primordium that gives rise to the respiratory system and the dorsal region that is the esophagus itself (2, 4, 6-9). At the beginning, the esophagus is short, but with the descent of the heart and lungs, it lengthens until the $7^{\text {th }}$ week $(2,4,6,7)$. The development of the esophagus is characterized by lengthening, widening, thickening, and histological changes $(9,12)$.

\section{Morphological \& histological development}

Epithelium: At the beginning, the epithelium is ciliated stratified columnar in type $(2,9)$. Menard et al. (13) reported ciliated stratified columnar epithelium at the $12^{\text {th }}-16^{\text {th }}$ week of intrauterine development. Sakai et al. (14) observed that ciliated cells were numerous at the esophagus epithelium of human fetuses at the $8^{\text {th }}$ week but were decreased after the $14^{\text {th }}$ week of development. At approximately the $8^{\text {th }}$ week, the lumen of the esophagus is partially obliterated by proliferation of cells in its wall. However, the lumen is recanalized by the formation and coalescence of large vacuoles. During the recanalization, the stratified columnar epithelium transforms into the stratified squamous epithelium $(2,4,7,8)$. In general, it has been accepted that in humans, the esophagus epithelium becomes stratified squamous within the $4^{\text {th }}$ month of development $(2,9)$; however, contradictory results have been reported about the exact time of this epithelial change in humans. Sakai et al. (14) observed an immature squamous stratified epithelium at the $14^{\text {th }}$ week and fully mature one at the $21^{\text {st }}$ week of development. Schaller et al. (15) observed the stratified squamous epithelium after the $23^{\text {rd }}$ week. Some authors suggest that transformation from ciliated columnar to stratified squamous continues until birth. It has been suggested that the ciliated cells persist in the upper and lower ends of the esophagus until the advanced period of the pregnancy might give rise to the cardiac glands located in the lamina propria (1).

Lamina propria: In human fetuses at the $19^{\text {th }}-20^{\text {th }}$ week, the glands have been rarely observed within this layer (16).

Muscularis mucosa: The muscularis mucosa, although very thin, has been detected at the $24^{\text {th }}-26^{\text {th }}$ week of the intrauterine development of human fetuses (16).

Submucosa: After the $27^{\text {th }}$ week, the submucosal glands were observed (16). The submucosal plexus has been shown within the $9^{\text {th }}$ week (17).

Muscularis externa: In human fetuses, the circular inner muscle layer has been detected at the $5^{\text {th }}$ week, whereas the outer longitudinal one has been detected at the $8^{\text {th }}$ week (9). At the 9th week, both of the layers were arranged as unin- 


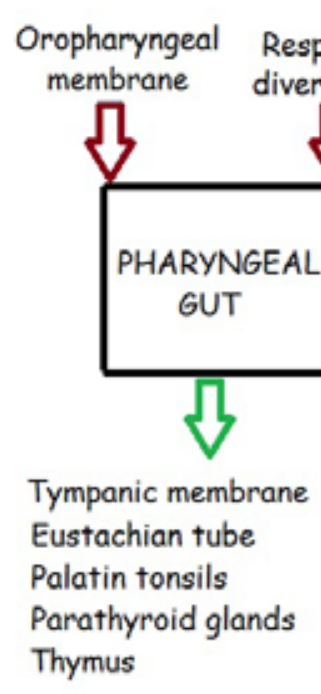

Tympanic membrane

Eustachian tube

Parathyroid glands

Thymus
Respiratory

iverticulum

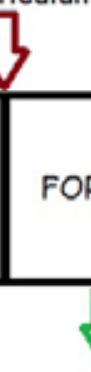

Respiratory

Stomach

Duodenum

Liver

Pancreas

Gallbladder
$2 / 3$ of transverse

Liver bud
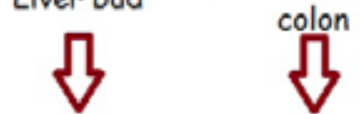

Cloacal membrane

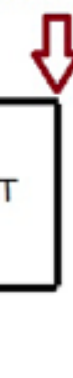

Figure 1. Main parts of the primitive gut tube and the organs derived from these regions are summarized (drawn by Esrefoglu M)

terrupted muscle cell layers $(18,19)$. The myenteric plexus was detected within the $7^{\text {th }}$ week of intrauterine development (17).

The esophagus continues to grow with elongation and thickening at postnatal period. It is approximately $8-10 \mathrm{~cm}$ at term, $12.5 \mathrm{~cm}$ at the end of the first year, $16 \mathrm{~cm}$ at the end of the $5^{\text {th }}$ year, and $19 \mathrm{~cm}$ at the end of the $15^{\text {th }}$ year. Its diameter is $5 \mathrm{~mm}$ at term and becomes $15 \mathrm{~mm}$ within the 5 th year. Just after the delivery, within the first 4 weeks, the lumen of the esophagus rapidly enlarges, and thickening of the mucosa is obvious. The proportion of the thicknesses of the mucosa/submucosa increases until the end of the $2^{\text {nd }}$ week (20).

\section{Functional development}

It has been shown that peristaltic capacity has been gained at the $1^{\text {st }}$ trimester of pregnancy (21). Three types of movement within the wall of the esophagus at the $2^{\text {nd }}$ trimester have been detected. These are the spontaneous opening of the lumen throughout the length of the esophagus, peristaltic contractions, and reflux from the stomach (22). Although peristalsis has been observed by ultrasonographic examination at the $2^{\text {nd }}$ trimester, spreading of peristalsis throughout the esophagus and at the lower esophageal sphincter has been found to be immature at term. Consequently, reflux of breast milk to the esophagus is very common. The pressure of the lower esophageal sphincter becomes equal to that of adults at approximately postnatal $3^{\text {rd }}-6^{\text {th }}$ week $(23)$. Thus, $75 \%-80 \%$ of newborns suffer from regurgitation within the first 2 weeks of their life. This problem almost completely (95\%) improves without intervention until the end of the $1^{\text {st }}$ year (24).
Figure 2 summarizes the prenatal and postnatal developmental changes of the esophagus in rats.

\section{Stomach}

\section{Histology of the stomach}

The stomach consists of the mucosa, submucosa muscularis (muscularis externa), and serosa. The mucosa is composed of the epithelium, lamina propria, and muscularis mucosa. The epithelium, which is simple columnar epithelium, functions as both lining and also secretory epithelium. The covering epithelium also protects the mucosa against acidic content of the stomach by producing mucus. The mucosa and submucosa together make longitudinal folds and ridges called 'rugae'. Under light microscope, the surface of the stomach contains numerous and relatively deep depressions called gastric pits (or foveola) that are formed by the surface epithelium. The underlying loose connective tissue, lamina propria, is largely occupied by gastric glands that open into the bottom of the gastric pits. The gastric glands are composed of five cell types, including the chief cells, parietal cells, mucous neck cells, enteroendocrine cells, and undifferentiated adult stem cells. The muscularis mucosa is composed of two layers, usually arranged as an inner circular and outer longitudinal layer. The submucosa is composed of dense connective tissue containing the nerve plexus of Meissner. The tunica mucosa is traditionally described as consisting an inner oblique, a middle circular, and an outer longitudinal layer. The myenteric nerve plexus is present between muscle layers. The outermost layer is the serosa, which is composed of the mesothelium and underlying thin, loose connective tissue $(10,11)$. 

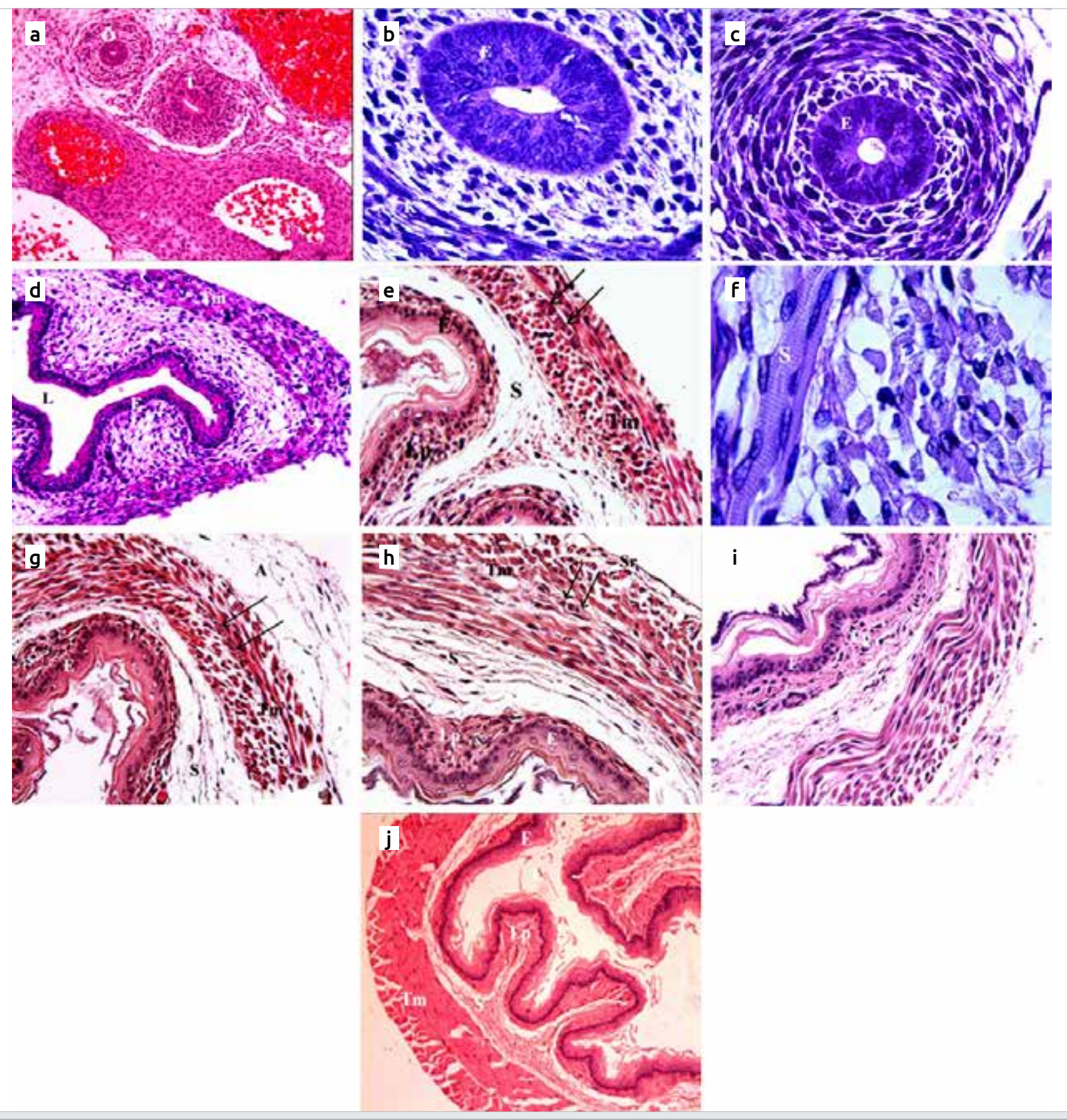

Figure 2. The prenatal changes within the features of the esophagus are shown in rats. A-B. Intrauterine $7^{\text {th }}$ day. The esophagus (Ö) and trachea are located together in the mesenchymal connective tissue. The epithelium (E) of the esophagus, stratified columnar in type, is surrounded by the mesenchymal connective tissue. A circular muscle layer (K) around the mesenchymal connective tissue is obvious. H\&E, X20; PAS, X100. C. Intrauterine 17 th day. In general, histological features of the esophagus are similar to those of the previous period; however, the muscle layer (K) is highly thickened. H\&E, X100. D. Intrauterine $20^{\text {th }}$ day. Histological features of the esophagus are now similar to those of adult rats. The lumen $(\mathrm{L})$ is highly enlarged; moreover, the wall of the esophagus has folds as a result of muscular contraction. Additionally, the epithelium (E) is stratified squamous in type, and the mesenchymal connective tissue (M) around the epithelium is thickened. The tunica muscularis (Tm) is now composed of two layers, namely, inner circular and outer longitudinal muscle layers. H\&E, X40. E-J. The postnatal changes within the features of the esophagus are shown in rats. E-F. Postnatal $5^{\text {th }}$ day. Stratified squamous epithelium (E), lamina propria (LP), submucosa (S), tunica muscularis (Tm), and myenteric plexus between muscle layers (arrows) are seen. Occasionally, there are striated muscle fibers within circular (S) and longitudinal (L) muscle layers. H\&E, X40; PAS, X100. G. Postnatal 10 th day. The epithelium (E), lamina propria (Lp), submucosa (S), tunica muscularis (Tm), and, additionally, adventitia (A) are obvious. The myenteric plexuses between muscle layers are marked with arrows. H\&E, X40. H. Postnatal 15th day. The layers of the wall of the esophagus are thickened. The outermost layer is here the serosa (S). H\&E, X40. I. Postnatal 20th day. Maturation of the layers is obvious. For example, now epithelium is keratinized stratified squamous in type (keratinization is expected in rodents). H\&E, X40. J. Young adult rat. Stratified squamous epithelium (E), lamina propria (LP), submucosa (S), and tunica muscularis (Tm) are seen. The wall of the esophagus is highly thickened. H\&E, X10. 


\section{Development of the stomach}

The development of the stomach is characterized by widening, thickening, and histological changes as well as locational and directional changes. The stomach appears as a fusiform dilatation of the foregut at the $4^{\text {th }}$ week of development (28). The growing stomach rotates $90^{\circ}$ clockwise around the longitudinal axis $(2,4-8)$. The rotation causes its left side to face anteriorly and its right side to face posteriorly. Additionally, during this rotation, the original posterior wall of the stomach grows faster than the anterior portion, forming greater and lesser curvatures. Before the rotation, the cephalic and caudal ends of the stomach originally lie in the middle, but during further growth, the stomach rotates around the anteroposterior axis. Thus, the caudal pyloric part moves to the right and upward, and the cephalic or cardiac portion moves to the left and slightly downward (28). At the $14^{\text {th }}$ week of development, the anatomical features including greater and lesser curvatures, fundus, corpus, and pylorus are formed in human fetuses (25). The diameter of the stomach increases as the fetus swallows amniotic fluid. At the $20^{\text {th }}$ week of development, the macroscopical and microscopical features of human fetuses are similar to those of newborns (26). In fact, at the $32^{\text {nd }}-34^{\text {th }}$ week of development, all of the layers including the mucosa, submucosa, muscularis, and serosa become more and more similar to those of the adult stomach (27). Cell differentiation within the stomach continues from early to late fetal period (9). It has been suggested that swallowed amniotic fluid influences cell proliferation and differentiation (28).

Epithelium: At the beginning, gastric epithelium is a stratified epithelium in type. It has the characteristics of stratified or pseudostratified epithelium at the $4^{\text {th }}$ week of development $(7,29)$, whereas pseudostratified epithelium at the $8^{\text {th }}-20^{\text {th }}$ week of development in human fetuses (30). Transition from stratified or pseudostratified epithelium to simple epithelium takes place at the $11^{\text {th }}-17^{\text {th }}$ week of development $(31,32)$. Some patchy areas of pseudostratified epithelium have been observed at the $12^{\text {th }}$ week of development in humans. Thus, epithelial transition may continue until the $20^{\text {th }}$ week (33). Chimalgi et al. (27) reported a simple cuboidal epithelium at the $15^{\text {th }}-20^{\text {th }}$ week of development, but a simple columnar epithelium at the $21^{\text {st }}-22^{\text {nd }}$ week of development. The exact mechanism of the epithelial transition is unknown. Nevertheless, the cells of the stratified epithelium might migrate to other parts of the body or undergo necrosis or apoptosis and finally disappear (28).

Gastric pits: For the first time, gastric pits begin to appear at the $8^{\text {th }}$ week at the fundus and corpus regions of the stomach (34). Kerry et al. (26) detected gastric pits at the $14^{\text {th }}$ week of development. However, they become similar to those of adults at the $15^{\text {th }}-16^{\text {th }}$ week of development.

Gastric glands: Although the mucosa has been formed until the $15^{\text {th }}$ week, between the $21^{\text {st }}$ and $24^{\text {th }}$ week and at the $18^{\text {th }}$ week, mucosal thickening is obvious (27). For the dif- ferentiation of the gastric glandular cells, various signals (35), hormones, and local growth factors derived from the mesenchyme are necessary (36). Morphological features of the glands become similar to those of adults at the $15^{\text {th }}-16^{\text {th }}$ week of development. It has been reported that the glands, which are acinar in type at the $15^{\text {th }}-20^{\text {th }}$ week, branch at the $21^{\text {st }}-22^{\text {nd }}$ week and later lengthen and become tubular at the $23^{\text {rd }}-28^{\text {th }}$ week of development. After the $28^{\text {th }}$ week, they continue to lengthen and become coiled (27).

Parietal cells: In fact, the cells of the fundic glands with high succinic dehydrogenase activity are parietal cells at the $8^{\text {th }}$ week of development (37). Nevertheless, the parietal cells with acidophilic cytoplasm can be recognized at the $12^{\text {th }}-15^{\text {th }}$ week of development $(27,33)$. These cells also observed within the pyloric glands at the $13^{\text {th }}$ week express intrinsic factor and hydrogen-potassium activity (38). It is now known that hydrochloric acid begins to be secreted at approximately the $32^{\text {nd }}$ week of development in humans ( 9 , 39). On the other hand, intrinsic factor has been detected at the $14^{\text {th }}$ week, its level increases seven times until the $25^{\text {th }}$ week of development (40). The level is the factor that becomes equal to that of adults within postnatal first 10 days (41).

Chief cells: The chief cells can be recognized at the $13^{\text {th }}$ week of development (42). Chimalgi et al. (27) observed this cell type at the $22^{\text {nd }}$ week. Some researchers reveal that these cells have pepsinogen activity at the $16^{\text {th }}$ week of development (39), whereas some of the others report that they do not have that activity until birth (42).

Mucous neck cells: Mucous cells can be detected at the $13^{\text {th }}$ week for the first time. They can produce mucus at the $16^{\text {th }}$ week of development (42). Chimalgi et al. (27) detected the mucous neck cells at the $22^{\text {nd }}$ week of development.

Enteroendocrine cells: It has been accepted that for the first time, enterochromaffin cells appear at the $11^{\text {th }}$ week of development $(43,44)$. Oberg et al. (45) observed these cells in the surface epithelium at the $9^{\text {th }}-10^{\text {th }}$ week. Additionally, they detected a new and interesting peptide function in food intake and growth hormone release at the $10^{\text {th }}$ week of development (46). The enteroendocrine cells containing gastrin and somatostatin have been detected at the $8^{\text {th }}$ week, glucagon and ghrelin at the $10^{\text {th }}$ week, and serotonin at the $11^{\text {th }}$ week of development $(47,48)$. G cells, another type of the endocrine cells, have been detected at the $18^{\text {th }}$ week of development (38). Throughout the fetal period, fetuses have a gastrin concentration of $10 \%$ of adults (49). Following birth, newborns in their first couple of days have higher serum gastrin levels than adults $(50,51)$.

Muscularis mucosa and submucosa: The muscularis mucosa appears at the $22^{\text {nd }}$ week of development. The submucosa is the thickest layer of the wall within the $15^{\text {th }}-20^{\text {th }}$ week and $25^{\text {th }}-27^{\text {th }}$ week (27). 

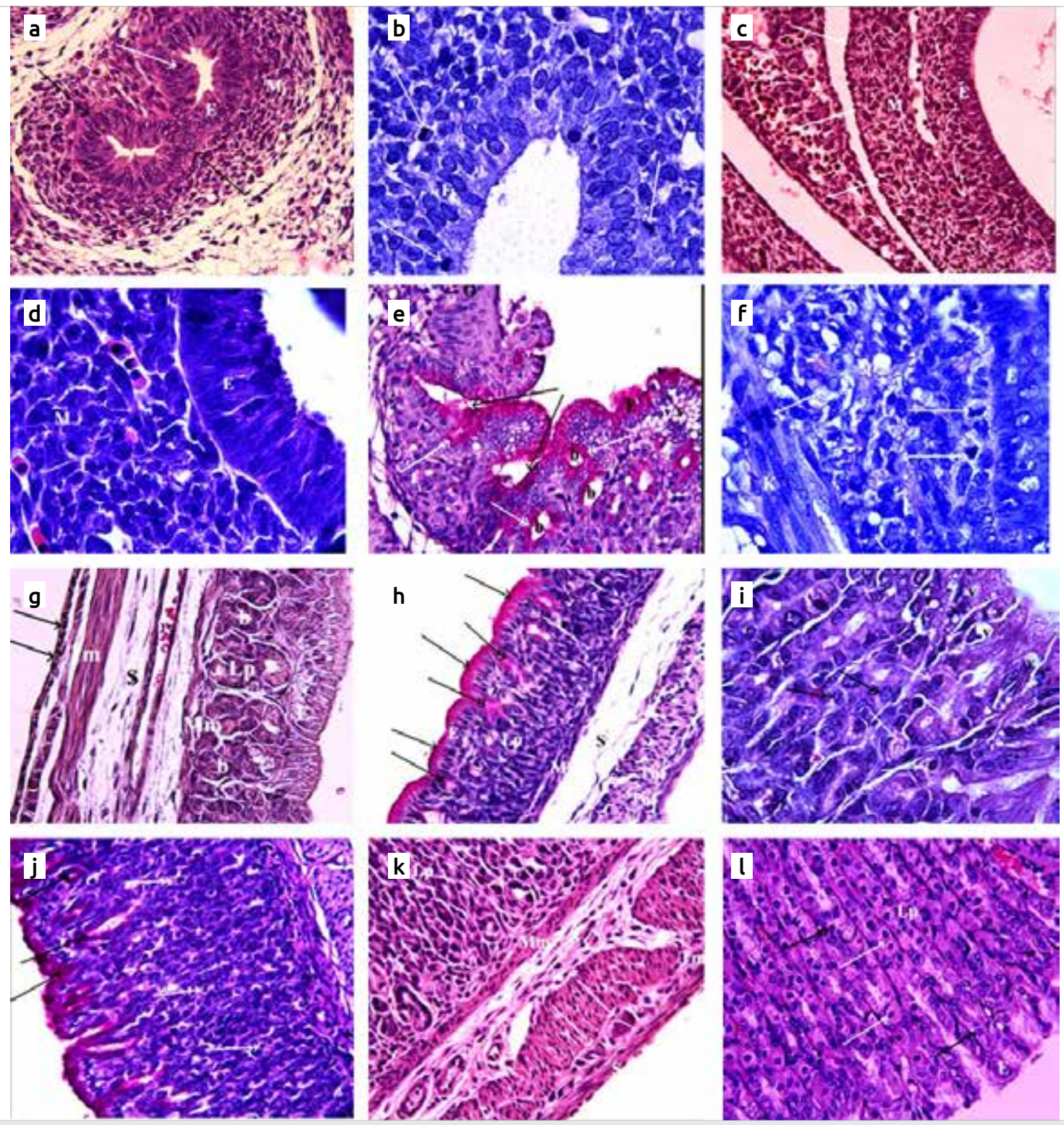

Figure 3. The prenatal changes within the features of the stomach are shown in rats. A. Intrauterine $7^{\text {th }}$ day. Pseudostratified columnar epithelium (E) and surrounding mesenchymal connective tissue (M) are observed. Basement membrane (black arrows) and mitotic figures within the epithelium (white arrows) are marked. PAS, X40. B. Intrauterine $10^{\text {th }}$ day. Pseudostratified columnar epithelium (E) and surrounding mesenchymal connective tissue (M) are observed. Mitotic figures within the epithelium and connective tissue are marked. H\&E, X100. C-D. Intrauterine $14^{\text {th }}$ day. Still, the wall of the stomach is composed of pseudostratified columnar epithelium (E) and surrounding vascular mesenchymal connective tissue (M). Hematopoietic cell groups within the liver are marked by white arrows. H\&E, X40; H\&E, X100. E-F. Intrauterine $20^{\text {th }}$ day. Foveola (black arrows) and glands (b) are formed. PAS positive mucus can be observed at the surface epithelium and glandular epithelium (white arrows). Additionally, a circular muscle cell layer (K) is now obvious at the periphery of the mesenchymal tissue. Mitotic figures within the connective tissue and muscle layer are marked with white arrows. PAS, X40; H\&E, X100. G-L The postnatal changes within the features of the stomach are shown in rats. G. Postnatal 5th day. Stratified columnar epithelium (E), lamina propria (Lp), muscularis mucosa (Mm), submucosa (S), tunica muscularis (Tm), and serosa (arrows) are obvious. Lamina propria is occupied by gastric glands (b) containing acidophilic parietal cells. H\&E, X40. H. Postnatal 10th day. Epithelium (E), lamina propria (Lp), muscularis mucosa (Mm), submucosa (S), tunica muscularis (Tm), and serosa (arrows) are observed. Gastric pits begin to appear (two-headed arrows). At the surface of the epithelium and lumen of the glands, PAS positive mucus is seen. PAS, X40. I. Postnatal 10th day. Epithelium is still stratified. Some vacuoles ( $v$ ) within the epithelium are seen. The parietal cells (white arrows) and chief cells (black arrows) are detectable. H\&E, X100. J. Postnatal 15th day. Mucosa is thickened, gastric pits are clearly recognizable, and PAS (+) mucus is increased (arrows). Many mitotic figures are present within the glandular epithelium (white arrows). K. Postnatal 20th day. All of the layers are thickened. Between the muscle layers, the myenteric nerve plexus is seen (arrows). H\&E, X40. L. Young adult. Simple columnar epithelium (E), lengthened glands in lamina propria (LP), and increased number of the chief (black arrows) and parietal cells (white arrows) are observed. H\&E, X40. 
Muscularis externa: The circular muscle layer appears at the $15^{\text {th }}$ week, and the longitudinal muscle layer appears at the $28^{\text {th }}$ week of development. Muscle layer becomes thicker especially between the $21^{\text {st }}$ and $24^{\text {th }}$ week and between the $28^{\text {th }}$ week and birth (27). Gastric motility can be detected approximately at the $20^{\text {th }}$ week of development (52).

Serosa: The serosa layer has been formed until the $15^{\text {th }}$ week of development (27).

Figure 3 summarizes the prenatal and postnatal developmental changes of the stomach in rats.

Acknowledgements: All of the figures are original and drawn by the first author and obtained from the thesis of Aslı Çetin with her approval.

Peer-review: Externally peer-reviewed.

Author Contributions: Conception - M.E., A.Ç., E.T.; Design M.E., A.Ç., E.T.; Supervision - M.E., A.Ç., E.T.; Funding - M.E., A.Ç.; Materials - M.E., E.T.; Data Collection and/or Processing M.E., A.Ç.; Analysis and/or Interpretation - M.E.; Literature Review - M.E., E.T.; Writer - M.E.; Critical Review - M.E.

Conflict of interest: No conflict of interest was declared by the authors.

Financial Disclosure: The authors declared that this study has received no financial support.

\section{References}

1. Larsen W. Development of the gastrointestinal tract. In: Sherman LS, Potter SS, Scott WJ, editors. Human Embryology, 4th ed. Philadelphia: Churchill Livingstone; 2009.p.435-477.

2. Moore KL, Persaud TVN. Klinik yönleri ile İnsan Embriyolojisi. (M. Yıldırım, İ. Okar, H. Dalçık, Çev.). 1. baskı, İstanbul: Nobel Matbaacilık; 2002.

3. Şeftalioğlu, A. Genel \& Özel İnsan Embriyolojisi. 3. baskı, Ankara: Tıp \& Teknik Yayıncılık Ltd. Şti; 1998.

4. Moore KL, Persaud TVN. Embriyoloji ve doğum defektlerinin temelleri. (S. Müftüoğlu, P. Atilla, F. Kaymaz, Çev.). 7. Baskı, İstanbul: Güneş Tip Kitabevleri; 2009.

5. Schoenwolf GC, Bleyl SB, Brauer PR, Francist-West PH. Larsen's Human Embryology. 4 th ed. Philadelphia: Churchill Livingstone; 2009.

6. Sadler TW. Langman's Medikal Embryology. 6. ed. Philadelphia: Williams and Wilkins; 2006.

7. Petorak İ. Medikal Embriyoloji. İstanbul: Beta Basım Yayım Dağıtım; 1984.

8. Kayalı H, Şatıroğlu G, Taşyürekli M. İnsan Embriyolojisi. 7. Baskı, İstanbul: Alfa Basım Yayım Dağıtım; 1992.

9. Carslon BM. Human embryology and developmental biology. 4th ed. Philadelphia: Mosby Elsevier; 2009.

10. Eşrefoğlu M. Özel Histoloji. 2. Baskı, İstanbul: İstanbul Tip Kitabevi; 2016.

11. Ross MH, Pawlina W. Histology. A Text and Atlas. 6th ed. Philadelphia: Lippincott Williams and Wilkins; 2011.
12. Gregersen H, Lu X, Zhao J. Physiological growth is associated with osephageal morphometric and biomechanical changes in rats. Neurogastroenterol Motil 2004; 16: 403412. [CrossRef]

13. Menard D, Arsenault P. Maturation of human fetal esophagus maintained in organ culture. Anat Rec 1987; 217: 348-354. [CrossRef]

14. Sakai N, Suenaga T, Tanaka K. Electron microscopic study on the esophageal mucosa in human fetuses. Auris Nasus Larynx 1989; 16: 177-83. [CrossRef]

15. Schaller G. Luminal surface of human esophagus during ontogeny. Z Mikrosk Anat Forsch 1978; 92: 675-699.

16. Tuncer I, Tosun M, Kalkan S, Soylu R. Özefagus'un gelişiminin 17 ile 32 haftalar arasındaki fetüslerde histomorfometrik olarak değerlendirilmesi. Erciyes Med J 2005; 27: 152-157.

17. Fu M, Tam PK, Sham MH, Lui VC. Embryonic development of the ganglion plexuses and the concentric layer structure of human gut: a topographical study. Anat Embryol 2004; 208: 33-41. [CrossRef]

18. Wallace AS, Burns AJ. Development of the enteric nervous system, smooth muscle and interstitial cells of Cajal in the human gastrointestinal tract. Cell Tissue Res 2005; 319:367-382. [CrossRef]

19. Fu M, Tam PK, Sham MH, Lui VC. Embryonic development of the ganglion plexuses and the concentric layer structure of human gut: a topographical study. Anat Embryol 2004; 208: 33-41. [CrossRef]

20. Rishniw M, Fisher PW, Doran RM, Meadows E, Klein WH, Kotlikoff MI. Smooth muscle persists in the muscularis externa of developing and adult mouse osephagus. J Muscle Res Cell Motil 2007; 28: 153-165. [CrossRef]

21. Bowie JD, Clair MR. Fetal swallowing and regurgitation: observation of normal and abnormal activity. Radiology 1982; 144: 877-878. [CrossRef]

22. Malinger G, Levine A, Rotmensch S. The fetal esophagus: anatomical and physiological ultrasonographic characterization using a high-resolution linear transducer. Ultrasound Obstet Gynecol 2004; 24: 500-505. [CrossRef]

23. Zuidema GD. Shackelford's Surgery of the Alimentary Tract, vol 1. Philadelphia: WB Saunders; 1996: 1-35.

24. Czinn SJ, Blanchard S. Gastroesophageal reflux disease in neonates and infants: when and how to treat. Paediatr Drugs 2013; 15: 19-27. [CrossRef]

25. Goldstein I, Reece E, Yarkoni S, Wan M, Green JL, Hobbins JC. Growth of the fetal stomach in normal pregnancies. Obstet Gynecol 1987; 70: 641-644.

26. Kelly EJ, Newell SJ. Gastric ontogeny: clinical implications. Arch Dis Child 1994; 71: 136-41. [CrossRef]

27. Chimmalgi M, Sant SM. Study of fetal stomach under light microscope. I Anat Soc Ind 2005; 54: 7-12.

28. Tommeras K, Cabero JL, Mardh S. Expression of extracellular matrix proteins in the fetal rat gastric mucosa. Anat Embryol 2000; 201: 149-156. [CrossRef]

29. De Lemos C. The Ultrastructure of endocrine cells in the corpus of the stomach of human fetuses. J Anat 1977; 148: 359384. [CrossRef]

30. Tremblay E, Ménard D. Differential expression of extracellular matrix components during the morphogenesis of human gastric mucosa. Anat Rec 1996; 245: 668-676. [CrossRef] 
31. Nomura, Y. On the submicroscopic morphogenesis of parietal cell in the gastric gland of the human fetus. Z Anat Entwickl 1966; 125: 316-356. [CrossRef]

32. Menard D, Arsenault P. Cell proliferation in developing human stomach. Anat Embryol 1990; 182: 509-516. [CrossRef]

33. Chénard M, Basque JR, Chailler P, Tremblay E, Beaulieu JF, Ménard D. Expression of integrin subunits correlates with differentiation of epithelial cell lineages in developing human gastric mucosa. Anat Embryol 2000; 202: 223-233. [CrossRef]

34. Arey LB. Developmental Anatomy. Philadelphia: WB Saunders; 1974

35. Fukamachi H, Mizuno T, Takayama S. Epithelial-mesenchymal interactions in differentiation of stomach epithelium in fetal mice. Anat Embryol 1979; 157: 151-160. [CrossRef]

36. Johnson LR. Functional development of the stomach. Annu Rev Physiol 1985; 47: 199-215. [CrossRef]

37. Grand RJ, Watkins JB, Torti FM. Progress in gastroenterology: Development of the human gastrointestinal tract - a review. Gastroenterology 1976; 70: 790-810.

38. Kelly EJ, Lagopoulos M, Primrose JN. Immunocytochemical localisation of parietal cells and G cells in the developing human stomach. Gut 1993; 34: 1057-1059. [CrossRef]

39. Keene MFL, Hewer EE. Digestive enzymes of the human fetus. Lancet 1929; 1: 767-769. [CrossRef]

40. Christie, DL. Development of gastric function during the first month of life. In Textbook of Gastroenterology and Nutrition in Infancy, editör. E. Lebenthal. New York: Raven; 1981. p.670

41. Agunod M, Yamaguchi N, Lopez R, Luhby AL, Glass GBJ. Correlative study of hydrochloric acid, pepsin and intrinsic factor secretion in newborns and infants. Am J Dig Dis 1969; 14: 400-14. [CrossRef]

42. Salenius P. On the ontogenesis of the human gastric epithelial cells. Acta Anat 1962; 50: 1-76. [CrossRef]
43. Singh I. The prenatal development of enterochromaffin cells in the human gastrointestinal tract. J Anat 1963; 97: 377-387.

44. Singh I. The distribution of cells of the enterochromaffin system in the gastrointestinal tract of the human fetuses. Acta Anat 1966; 64: 544-558. [CrossRef]

45. Oberg K. Gastric Neuroendocrine cells and secretory products. Yale J Biol Med 1998; 71: 149-54.

46. Rindi G, Necchi V, Savio A, Torsello A, Zoll M, Locatelli V, et al. Characterisation of gastric ghrelin cells in man and other mammals: studies in adult and fetal tissues. Histochem Cell Biol 2002; 117: 511-519. [CrossRef]

47. Stein BA, Buchan AM, Morris J, Polak JM. The ontogeny of regulatory peptide-containing cells in the human fetal stomach: an immunocytochemical study. J Histochem Cytochem 1983; 31: 1117-25. [CrossRef]

48. Rindi G, Savio A, Torsello A, Zoli M, Locatelli V, Cocchi D, et al. Ghrelin expression in gut endocrine growths. Histochem Cell Biol 2002; 117: 521-5. [CrossRef]

49. Track NS, Creatzfeldt C, Litzenberger J, Neuhoff C, Arnold $\mathrm{R}$, Creutzfeldt W. Appearance of gastrin and somatostatin in the human fetal stomach, duodenum, and pancreas. Digestion 1979; 19: 292-306 [CrossRef]

50. Euler AR, Byrne WJ, Meis PJ, Leake RD, Ament ME. Basal and pentagastrin stimulated acid secretion in newborn human infants. Pedlatr Res 1979; 13: 36-37. [CrossRef]

51. Lucas A, Adrian TE, Christofides N, Bloom SR, Aynsley-Green A. Plasma motilin, gastrin, and enteroglucagon and feeding in the human newborn. Arch Dis Child 1980; 55: 673-77. [CrossRef]

52. Lebenthal A, Lebenthal E. Ontology of the small intestinal epithelium J Parental Enteral Nutr 1999; 23: 5. 